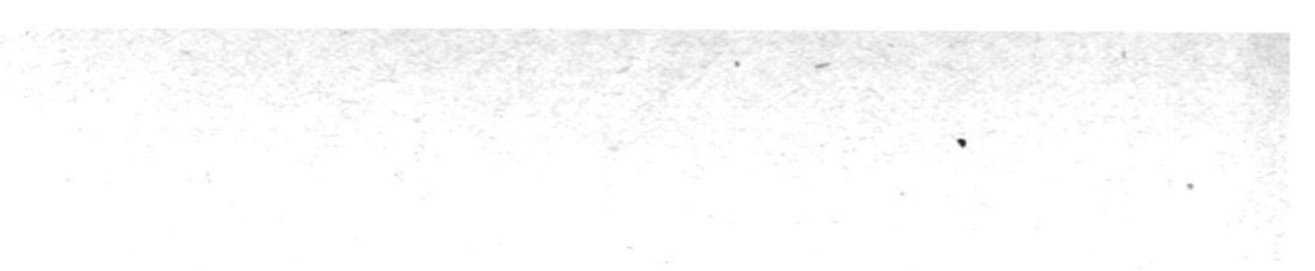

\title{
POLITIEKE ONTWIKKELING IN SURINAME NA DE INWERKINGTREDING DER INTERIM-REGELING
}

\author{
DOOR \\ E. Tuyl Schuitemaker - van Steenbergen ${ }^{1}$ )
}

A De partijen

De politieke partijen ontstonden vrijwel tegelijk met de naoorlogse autonomie-beweging.

De eerste groeperingen ontstonden in Hindostaanse en Javaanse kringen. In Mei 1946 vormde zich de Moslem Partij Suriname, een politieke organisatie van Mohamedanen. Het jaar daarop werden verschillende partijen door Hindu's en Javanen opgericht: de Hindu Partij Suriname, de Hindu-Javaanse Politieke Partij, de Hindu Oranje Partij, de Kaum Tani Persatuan Indonesia en de Pergerakan Bangsa Indonesia Surinam. Het streven der Indonesische partijen is gericht op welvaartsverbetering voor de Indonesische bevolkingsgroep en hun uiteindelijk doel is de terugkeer naar Indonesië mogelijk te maken voor iedere Indonesiër die dit wenst; men tracht de band met Indonesië te behouden en zich zoveel mogelijk afzijdig te houden van de Surinaamse politiek.

In 1949 gingen de Moslem Partij, de Hindu Partij en de Hindu-Javaanse Politieke Partij een fusie aan, en werd de Verenigde Hindustaanse Partij opgericht. Aan deze organisatie was geen lang leven beschoren want in 1950 kwam het tussen Hindu's en Moslemleden tot een scheuring in verband met de NPS kwestie (zie onder B). De naam ,,Verenigde Hindustaanse Partij" werd gehandhaafd voor de organisatie der na deze scheiding overgebleven Hindu's onder leiding van de heer LACHMON.

In hetzelfde jaar werd een nieuwe Hindostaanse partij opgericht, de Congrespartij; doel: een democratisch-socialistische maatschappij. Ook de Javanen vormden een nieuwe partij in 1949, de Perhimpunan Kemadjuan Rakjat Indonesia, opgericht door vroegere leden van de Kaum Tani Persatuan Indonesia, die geen vertrouwen meer stelden in hun vertegenwoordigers in de Staten, de heren Soemita en Karamat ALI. Andere Indonesische organisaties zijn: de Shahabatul Islam, de

1) Bijdrage van het Documentatiebureau voor Overzees Recht te Leiden. Bronnen: De West, Beurs- en Nieuwsberichten voor de Nederlandse Antillen, Surinaams Nieuwsbulletin, Weekbericht Vereniging Bedrijfscontact Nederland-Suriname en organen van politieke partijen. Afgesloten in September 1951. 


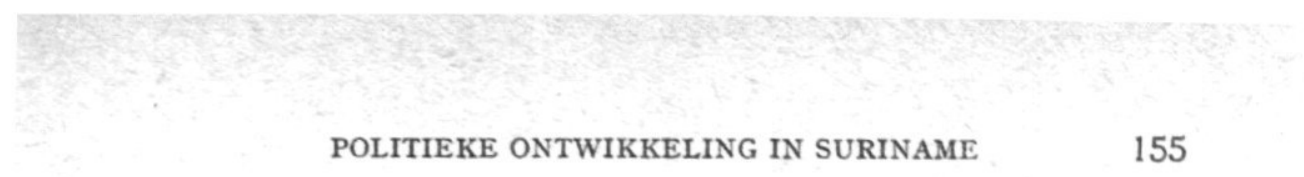

Parhimpunan Islam Indonesia en de Margo Oetomo (zie de artikelen van Ismael in Indonesië 4, p. 188, en De nieuwe Stem 5, p. 679).

Wat de Creoolse bevolkingsgroep betreft: de Katholieken verenigden zich in de Progressieve Surinaamse Volkspartij, die gebaseerd is op de beginselen der R.K. godsdienst. De grote massa der Creolen groepeerde zich in de Nationale Partij Suriname. Een aparte organisatie vormden nog een aantal Creolen in de Neger Politieke Partij. Zowel de P.S.V. als de N.P.S. en de N.P.P. werden in 1946 opgericht.

In 1950 kwam het tot een scheuring in de N.P.S.; enkelen van de afgescheiden leden, de heren EliAzer en VAN DER SCHROEF namen met de heren Calor, de Miranda, Wijngaarde en Schoonhoven het initiatief tot de oprichting van een nieuwe partij, de Democratische Nationale Partij. Ook in de P.S.V. dreigden spanningen, als gevolg van de N.P.S. kwestie (zie onder B), die zich echter nog niet in een daadwerkelijk uiteengaan realiseerden; wel traden enkele leden uit de partij toen deze het besluit nam niet aan de verkiezingen 1951 deel te nemen.

Voorts moeten nog genoemd worden de Christelijke Sociale Partij gevormd door leden van de Broedergemeente der Hernhutters, en de Agrarische Partij, die opgericht werd in 1948 door landbouwende groepen der bevolking, voornamelijk ten behoeve van de verkiezingen.

\section{B Politieke moeilijkheden}

Reeds enkele maanden na de inwerkingtreding van de interimregeling op 20 Januari 1950, ontstond in Suriname grote politieke onrust die voortduurde tot in begin 1951 de Staten ontbonden en nieuwe verkiezingen gehouden werden.

Bij de eerste algemene verkiezingen in Mei 1949 behaalde de N.P.S. de absolute meerderheid en veroverde daarmee 13 van de 21 zetels in de Staten; van de overige zetels vielen er 6 toe aan de V.H.P. en 2 aan de K.T.P.I. Toch heeft de N.P.S.-fractie niet de invloed uitgeoefend die hierdoor mogelijk zou zijn geweest, daar haar leden verdeeld waren door persoonlijke veten. Op de politieke strijd, die zich in de loop van 1950 ontwikkeld heeft, is deze onderlinge vijandige gezindheid van grote nvloed gebleken.

Zo ontstond direct na de stembusoverwinning reeds wrijving doordat de heren Findlay en PENGel door wisten te drijven dat fractieleden geen lid meer mochten zijn van het hoofdbestuur der N.P.S., waardoor de heren van der Schroeff, WijngaArde en Eliazer gedwongen waren uit het hoofdbestuur te treden.

De verwijdering tussen de fractieleden werd groter en liep tenslotte uit op een scheuring in de partij door een motie van wantrouwen van de N.P.S. tegen de landsminister van onderwijs, volksontwikkeling en volksgezondheid LichtVELD, naar aanleiding van het ontslag van de gouvernementsarts vaN OMMEREN door dezen. Na herhaalde klachten van de geneesheer-directeur over de heer van OMMEREN (die tevens N.P. S.-Statenlid was) wegens financieel en materieel wanbeheer en wangedrag (niet opvolgen van bevelen), werd hem tegen 4 April zijn ontslag aangezegd door landsminister LICHTVELD, nadat hij verschillende malen gewaarschuwd was. Een commissie van onderzoek, die op verzoek van 
de voorzitter der N.P.S. de kwestie onderzocht, was het eens met dit besluit.

Op ro April nam de afdeling Paramaribo van de N.P.S. een motie van wantrouwen aan tegen minister Lichtveld (zelf lid van de N.P.S.). De afdelingen Nickerie, Onverwacht en Osembo, la Prospérité en Coronie stonden achter deze motie; de afdelingen Marowijne, Paranam en Commewijne waren er tegen.

Naar aanleiding van de kwestie-van Ommeren werd door de Statenleden Pengel, Kolader, Bos Verschuur, Findlay (allen N.P.S.leden) en Mohamedradja (V.H.P.-lid) een interpellatie-voorstel bij de Staten ingediend betreffende de wantoestanden die bij de medische dienst zouden bestaan. De Staten aanvaardden het en op 20 April beantwoordde minister Lichtveld de interpellatie. Bij de debatten werden felle beschuldigingen over en weer geuit. De medici werden beschuldigd van geldzucht (financieel wanbeheer), de minister van dictatuur.

Op het partijcongres van de N.P.S. op 18 Juni werd de motie van wantrouwen tegen de heer Lichtveld van 10 April met 24 tegen 10 stemmen aangenomen. Daarop moest de motie de weg naar de Staten vinden. Het was te verwachten dat er een verwarde toestand zou ontstaan, daar verschillende N.P.S.-fractieleden tegen de motie waren.

$6 \mathrm{Juli}$ werd tenslotte de belangrijke dag in de politieke strijd. Op deze datum werd de motie van wantrouwen tegen minister LICHTVELD door enkele N.P.S.-fractieleden (Findlay, Pengel en van Ommeren) in de Staten gebracht en met 13 tegen 7 stemmen (de heer LACHMON ontbrak) verworpen. De Statenleden RaAtgever, de la Fuente, Eliazer, Wong, Bos Verschuur, Lauriers, WijngaArde en Van DER SchroefF bedankten voor het lidmaatschap van de N.P.S., als tegenstanders van de motie. $\mathrm{Zij}$ trokken hieruit echter niet de consequentie dat zij uit de Staten behoorden te treden. Dit was voor de heren FInDLAY, PENGel en van OMMEREN reden om het vertrouwen in de leiding van de voorzitter VAN DER SCHROEFF op te zeggen en ontbinding van de Staten gevolgd door nieuwe verkiezingen te eisen. Ook de Congrespartij was voor Statenontbinding, evenals de P.B.I.S. die hoopte na ontbinding een betere vertegenwoordiging van de Indonesiërs in de Staten te bereiken.

Op 7 Juli bedankten ook de zes leden der Regeringsraad als partijlid van de N.P.S., en boden hun ontslag aan bij de Gouverneur, op grond van het feit dat er door het verbreken van de meerderheid der N.P.S. in de Staten geen één-partijregering meer kon zijn, en dat zij geen lid meer waren van de N.P.S.

In het schrijven aan het hoofdbestuur der N.P.S., waarin de leden van de regeringsraad het bedanken als lid van de N.P.S. motiveerden, werd een brief aangehaald van 14 April, waarin zij waarschuwden tegen de methoden van de N.P.S. om over de hoofden der Staten heen moties van wantrouwen tegen de regeringsraad aan te nemen. Dit noemde het schrijven onstaatsrechtelijk, daar de regeringsraad verantwoordelijk is aan de Staten en niet aan de partij, en bovendien practisch bezwaarlijk, daar de rechtsstaat in gevaar zou komen als de regering of de Staten adviezen of wilsuitingen van politieke partijvergaderingen zouden moeten opvolgen. Het feit dat de N.P.S. deze waarschuwing in de wind had 
geslagen was voor de landsministers aanleiding om uit de partij te treden.

$\mathrm{Na}$ vele besprekingen o.a. met de voorzitter der N.P.S., de heer LIM APO, die Statenontbinding eiste, besloot de Gouverneur de Staten niet te ontbinden, en een informatieve opdracht (!) te geven aan de heren Drielsma en Buiskool om een nieuw kabinet te vormen. Het ontslag van de regeringsraad werd vooreerst in beraad gehouden.

Toen echter de Statenleden, die tegen de motie van wantrouwen in minister Lichtveld hadden gestemd (minus de heer DE LA Fuente, die zich hierbij niet aansloot, en aangevuld met de heer LACHMON, dus in totaal 7 voormalige N.P.S.-leden, 4 V.H.P.-leden en 2 K.T.P.I.-leden), een coalitie vormden, waardoor een meerderheid in de Staten werd bereikt waarop de regering kon steunen, trokken de heren DrIELSMA en BuISKoOL hieruit hun consequentie, en deelden de Gouverneur mee dat zij een definitieve opdracht tot het vormen van een kabinet niet konden aanvaarden. Hierop besloot de Gouverneur het ontslag van de regeringsraad niet aan te nemen. De coalitie sprak zich uit voor een aanblijven van de oude regering, eventueel uitgebreid met enkele leden. De enige wijziging in de regeringsraad was, dat de heer DRIELSMA op zijn verzoek eervol werd ontslagen als minister van Financiën en opgevolgd door de heer CURRIE, wnd districtscommissaris van Nickerie.

Daar wegens het verlof van premier DE MIRANDA de ministers CurRIE en BRAKKE overbelast waren (ieder met twee portefeuilles, resp. met financiën/justitie en openbare werken en verkeer/economische zaken), was de regeringsraad voornemens het aantal ministers uit te breiden tot het door de Landsregeling gestelde maximum van 9 leden; van dit plan is echter niets gekomen.

De N.P.S. legde zich bij de nieuwe situatie niet neer. De N.P.S.-afdeling Paramaribo nam een motie van wantrouwen aan tegen de Staten die huns inziens in de toenmalige samenstelling het vertrouwen der kiezers niet meer bezaten.

Een noodlottig gevolg voor de V.H.P. van deze kwestie was, dat er ook een scheuring ontstond in deze partij; Moslims en Hindu's kwamen tegenover elkaar te staan, waardoor het politieke conflict dreigde om te slaan in een godsdienstig. De twee Moslim-leden van de V.H.P.-fractie, de heren Mohamedradja en Jamaludin, schaarden zich aan de zijde der N.P.S. De tegenstelling werd nog verscherpt toen deze heren, tijdens de informatieve besprekingen die de heren Drielsma en Buiskool met de Statenleden hielden, verklaarden dat de Moslims een zetel in het kabinet zouden eisen indien dit werd uitgebreid met een Hindu.

De verhouding coalitie-oppositie werd $13: 8$, toen in de plaats van de heer DE LA FUENTE, die zijn Statenlidmaatschap opgaf, bij tussentijdse verkiezingen op 10 October een N.P.S.-lid , de heer JuglaLL, werd gekozen. De verkiezingsstrijd hierbij was hevig en ging hoofdzakelijk tussen de onafhankelijke candidate mevrouw MonKaU-REDMOND (die gesteund werd door de P.S.V. en de D.N.P.) en de heer Juglall; de D.N.P. stelde zelf geen candidaat, de C.S.P. stemde op de N.P.S.candidaat evenals de Congrespartij; van de Hindustanen-candidaat, Hasan Ali, werd weinig vernomen. Juglall won de strijd en dit was voor de N.P.S.-leden een aanwijzing dat de kiezers voor Statenontbinding waren. Tegenstanders van de N.P.S. wezen er echter op dat van de 35.681 kiezers te Paramaribo slechts 16.901 hun stem uitbrach- 
ten. Wel was het verschil tussen de uitgebrachte stemmen op de verschil- lende candidaten zeer groot, resp. Juglall: Monkau: Hasan Ali = $10.038: 5.138: 530$.

Direct na de verkiezing van de heer Juglall had de heer Lim Apo weer een onderhoud met de Gouverneur waarin hij de wens tot Statenontbinding herhaalde. De coalitie zag in de N.P.S.-overwinning nog geen reden voor de Gouverneur om de Staten te ontbinden, daar de regering nog steeds kon rekenen op de meerderheid in de Staten. Deze meerderheid werd echter wel zeer klein toen de K.T.P.I. besloot uit de ćoalitie te treden: het zeteltal van de coalitie kwam hiermee op 11. De K.T.P.I. deed dit ,,omdat ze het niet juist achtte na de N.P.S.-stembusoverwinning de wil van het volk te negeren". Wel verklaarde KARAMAT ALI dat zijn partij niet overliep naar de oppositie: de K.T.P.I. zou onafhankelijk haar standpunt bepalen, maar in de praktijk schaarde de K.T.P.I. zich achter de oppositie, die dus over 10 stemmen beschikte.

De Statenvergadering die volgde op de verkiezing van Juglall was zeer rumoerig; beschuldigingen over en weer waren niet van de lucht; aan de heren Pengel en Findlay werd het woord ontnomen, toen zij wederom weigerden de heer VAN DER SCHROEFF als voorzitter te erkennen.

In antwoord op het herhaalde verzoek van de N.P.S. om de Staten te ontbinden deelde de Gouverneur op $2 I$ October mee dat de Staten niet ontbonden zouden worden, daar de regering meende ,,dat Suriname in de eerste plaats voor de opbouw op economisch, sociaal en cultureel gebied, politieke rust behoeft". Voorts besloot de regering op zeer korte termijn voorstellen te doen tot herziening van het kiesreglement in de richting van evenredige vertegenwoordiging met personenstelsel, overeenkomstig een door mr Buiskool ontworpen stelsel (zie ad D). Na de totstandkoming van een herzien kiesreglement zouden de Staten ontbonden worden.

De reactie van de N.P.S. op deze mededeling was uiteraard afwijzend. Van Katholieke zijde betuigde men instemming met het besluit om de Staten niet te ontbinden, maar over een wijziging van het kiesstelsel was men weinig enthousiast. De P.S.V., de C.S.P. en de Congrespartij waren voorstanders van evenredige vertegenwoordiging.

Op I5 November deelde de coalitie aan de Gouverneur mee, dat, wegens het ordeverstorend gedrag van enkele leden (waarmee de oppositie werd bedoeld) en het misbruiken van de parlementaire onschendbaarheid, vruchtbare arbeid in de Staten in het belang van Suriname niet langer mogelijk was; de coalitie was vastbesloten niet meer aan de Statenvergaderingen deel te nemen, zolang het bestaande Reglement van Orde onvoldoende voorzieningen bevatte ter handhaving van de orde in de vergaderingen.

In een op I6 November gepubliceerd communiqué verklaarde de landsregering, dat tengevolge hiervan een vijftal wettelijke regelingen die vóór 1 Januari 1951 behandeld moesten worden niet aan de orde zouden komen. Onder deze regelingen waren er twee, $\mathrm{nml}$. de begroting 1950 en de verlenging van het octrooi van de Surinaamsche Bank, waarvan de totstandkoming vóór 1 Januari 1951 absoluut noodzakelijk was, aangezien anders na 1 Januari 1951 geen betalingen uit 'sLands kas meer mogelijk zouden zijn en de circulatiebank zou ophouden te 


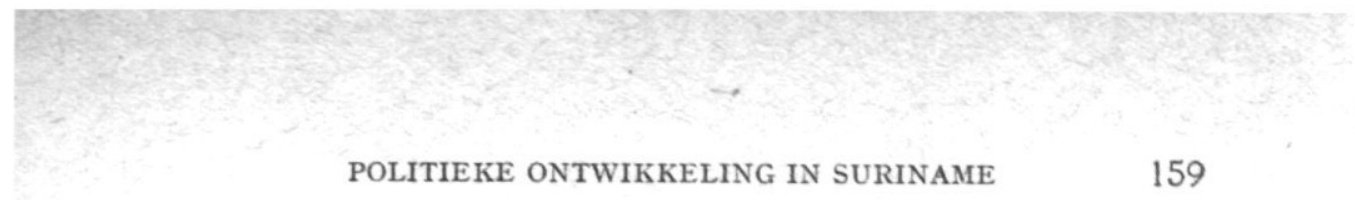

bestaan. Daar ontbinding der oude Staten en verkiezingen voor nieuwe Staten niet vóór eind 1950 gereed zouden komen, en vergaderen in de oude Staten onmogelijk was geworden, besloot de landsregering een andere oplossing voor de moeilijkheden te zoeken. De enige mogelijkheid hiertoe zag zij in de toepassing van artikel 174 van de Landsregeling, bepalende dat, wanneer een orgaan niet of niet voldoende voorziet in hetgeen het krachtens een wet, Algemene Maatregel van Bestuur, verdrag of andere internationale overeenkomst moet verrichten, een Nederlandse wet kan bepalen welk gezag zodanig orgaan vervangt. Hiermee besloot de landsregering dus de tussenkomst der Nederlandse regering in te roepen, teneinde bij de wet een gezag aan te wijzen ter vervanging van de Staten. Taak van dit orgaan zou zijn: vaststelling der begroting 1950, verlenging van het octrooi der Surinaamsche Bank, het vaststellen van twee verordeningen over belastingen en herziening van het kiesreglement. Daarna zou tot Statenontbinding en nieuwe verkiezingen worden overgegaan.

Hier zij melding gemaakt van een artikel van mr Buiskool, waarin hij zich afvroeg of het staatsrechtelijk gezien wel nodig was dat de begroting 1950 en de verlenging van het Bankoctrooi vóór 1 Januari 1951 werden afgehandeld. Hij betoogde dat het, in de impasse waarin Suriname verkeerde, misschien niet ongeoorloofd was om art. 113 der Landsregeling aldus te interpreteren, dat ,,voorafgegaan jaar” opgevat werd als voorafgegaan dienstjaar. In dat geval zou de begroting van 1949 als basis voor 1951 kunnen dienen. Wat het octrooi betreft: de verlenging van het octrooi volgens de Surinaamse Bankwet van 1928 geschiedde op 7 November 1949 bij Koninklijk Besluit en in Juni 1950 bij landsverordening. Verlenging van het octrooi kan echter bij landsbesluit gebeuren, omdat zij een eenvoudige daad van uitvoering is.

De oppositie reageerde met een protest tegen toepassing van art. 174; in een brief van 16 November aan de landsregering voerde de oppositie aan dat de 11 leden der coalitie behoorden af te treden, terwijl de Staten dan met de 10 oppositieleden zouden kunnen voortwerken. Naar aanleiding hiervan ontstond een polemiek tussen de heer Buiskool en de heer VAN DER SchroEfF over de kwestie van het quorum in de Staten (zie onder C). Voorts eiste de oppositie in een brief aan de voorzitter van de Staten een algemene vergadering ter bespreking van het besluit der landsregering, hetgeen door de voorzitter geweigerd werd. Ook naar de Nederlandse regering verzond de oppositie een protest, waarin verzocht werd een delegatie uit Suriname te willen ontvangen ter toelichting van de situatie.

Ook de C.S.P. wees in een motie die aan het Ministerie van Uniezaken en Overzeese Rijksdelen gezonden werd de toepassing van art. 174 af. De V.H.P. echter was het er wèl mee eens. Pijnlijker nog werd de toestand doordat ziekte van cen coalitielid (de heer LACHMON) de verhouding tussen coalitie en oppositie op 10: 10 bracht.

Op 27 November voerden de landsministers BRAKKE en ZAAL een informatieve bespreking met de Heren Moнamedradja, Sozmita en Pengel. Hierin werd meegedeeld dat de regering bereid was af te treden indien de begroting 1950, de verlenging van het octrooi der Surinaamsche Bank en de opcenten-verordening behandeld zouden worden; daarna zou het Statencollege ontbonden worden. Daar de coalitie af- 
wijzend stond tegenover het voorstel, was ook deze kans op een oplossing echter verkeken.

Op het verzoek van de Gouverneur om art. 174 toe te passen antwoordde de Nederlandse minister van overzeese rijksdelen, dat pas wanneer alle andere middelen om een ordelijk bestuur te handhaven geprobeerd en zonder effect gebleven zouden zijn, de Nederlandse regering toepassing van art. 174 kon overwegen. $\mathrm{Zij}$ verklaarde zich echter bereid zich door een Surinaamse delegatie voor te laten lichten.

Coalitie en oppositie stelden hierop ieder een delegatie samen om haar standpunt in Nederland toe te gaan lichten.

Bij de besprekingen die de delegaties in Nederland met minister van MaArseveen en de West-Indische commissie van de Tweede Kamer voerden bleek wederom dat men hier geneigd was de kwestie ais een interne Surinaamse aangelegenheid te beschouwen. Slechts in het uiterste geval was men bereid tot toepassing van art. 174 en dan wilde men de bevoegdheid tot wijziging van het kiesstelsel daartoe niet rekenen daar volgens de minister het kiesstelsel geen noodtoestand kan opleveren en dit bovendien te zeer zou ingrijpen in de verkregen zelfstandigheid van Suriname.

Tenslotte werd op 2 I December een overeenkomst tussen de delegaties bereikt van de volgende inhoud:

$a$, ,de delegaties verbinden zich de ontwerpen betreffende de begroting 1950, de verlenging van het Surinaamse Bankoctrooi, twee belastingsvoorzieningen en de wijziging van het Reglement van Orde met de meest mogelijke spoed af te handelen";

$b$, ,aan het oordeel van de Gouverneur wordt overgelaten of hij dadelijk daarna tot ontbinding der Staten zal overgaan. Mocht dit gebeuren dan is de behandeling van de wijziging van het kiesreglement door de oude Staten niet nodig".

De coalitie had dus haar eis tot behandeling van het nieuwe kiesreglement laten vallen, terwijl de oppositie toestemde in behandeling van het Reglement van Orde.

Ondanks dit hoopvolle resultaat dreigden er spoedig nieuwe moeilijkheden over de kwestie of de overeenkomst was bereikt op basis van Statenontbinding of niet. De oppositie wees erop dat Statenontbinding de voorwaarde was waarop zij bereid was in de Staten de aanhangige wetsontwerpen te behandelen, en dat bovendien de hele strijd der laatste maanden geen zin zou hebben gehad indien men de eis tot Statenontbinding had laten vallen. De coalitie hield zich aan het communiqué waaruit niet blijkt of Statenontbinding de basis der overeenkomst was.

Intussen hield de oppositie zich aan de afspraak en werden in de vergadering van 29 December de begroting 1950, de verlenging van het Bankoctrooi en twee belastingontwerpen aangenomen.

$\mathrm{Na}$ verschillende vergaderingen met regeringsraad en fractieleden deelde de Gouverneur op 3 Januari I95I zijn besluit mede om de Staten zo spoedig mogelijk te ontbinden. De Landsministers Hewitt en LichtVELD stelden hun portefeuilles beschikbaar daar zij het niet eens waren met dit besluit tot Statenontbinding vóórdat het kiesreglement gewijzigd was. HEwitT bleef op verzoek van de Gouverneur zijn werkzaamheden vervullen tot de nieuwe verkiezingen, zodat het kabinet niet 


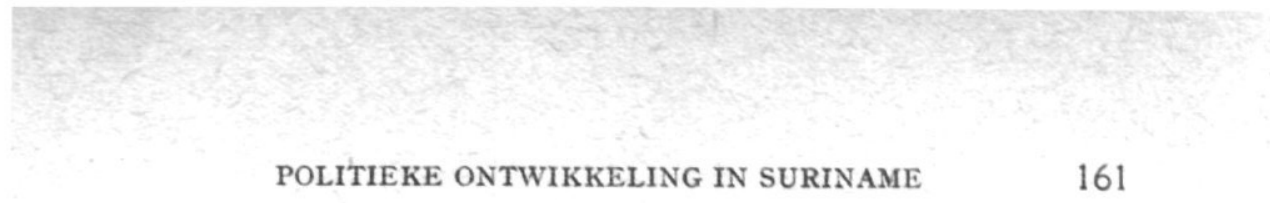

aangevuld behoefde te worden, terwijl voorts de portefeuille van onderwijs en volksgezondheid werd verdeeld onder de ministers $Z_{\text {AAL }}$ en HewitT.

De coalitie protesteerde ernstig tegen het besluit en sprak scherpe afkeuring uit over de ministers ZAAL, BRAKKE en CURRIE, die bereid waren geweest het besluit van de Gouverneur te contrasigneren.

De regeringsraad legde in een uitvoerig communiqué van 5 Januari ' $5 \mathrm{I}$ een verklaring af over de gebeurtenissen die geleid hadden tot het besluit om de Staten te ontbinden. Geconstateerd werd dat het communiqué van 21 October (Statenontbinding na wijziging van het kiesstelsel) door de feiten achterhaald was en dat het na de besprekingen der delegaties in Nederland duidelijk was dat Nederland zich, ook indien art. 174 werd toegepast, niet zou bezig houden met wijziging van het kiesreglement, zodat de oppositie gevoeglijk aan kon nemen dat, zelfs bij toepassing van art. 174, Statenontbinding onmiddellijk zou volgen. De inhoud van de op 21 December tussen de delegaties bereikte overeenkomst moest dan ook in het licht van het voorgaande worden beschouwd.

Op de beslissing der drie landsministers die besloten hadden het ontbindingsbesluit te contrasigneren zijn verder van invloed geweest:

1 de verklaring die de leider der coalitie-delegatie Lichtveld voor zijn vertrek uit Nederland had afgelegd ( $\mathrm{nml}$. dat er geen overeenstemming was bereikt en dat wijziging van het kiesstelsel vóór Statenontbinding noodzakelijk was, aangezien het bestaande systeem partij-dictatuur in de hand werkte);

2 de wankele positie van de coalitie (die o.a. bleek uit het feit, dat de op 4 Jan. uitgeschreven huishoudelijke vergadering ter behandeling van het Reglement van Orde geen voortgang vond wegens afwezigheid van een lid der coalitie)

3 de plotselinge ontslagaanvraag van premier de Miranda op 28 December 1950 , ,om wiens behoud in de landsregering de coalitie destijds voornamelijk tot stand kwam",

4 de gedachte, die ook in Nederland werd voorgestaan, om het kiesstelsel te behandelen op de Ronde Tafel Conferentie met de West.

Toch gaven de tegenstanders van de N.P.S. de strijd niet op. Verschillende groeperingen, zoals Hindu's en P.S.V., sloten zich aaneen teneinde bij de verkiezingen gezamenlijk op te treden. De coalitie leverde felle critiek op de Gouverneur, speciaal op het feit dat hij destijds met een minderheid in de Staten (de oppositie) had geconfereerd over de aanvulling van het kabinet, toen het nog niet bekend was dat minister Hewitr aan zou blijven; en ook dat de Gouverneur het besluit tot Statenontbinding had genomen voordat het Reglement van Orde behandeld was, zoals op 21 December was overeengekomen.

Op II Januari I95I kwam het nieuwe Reglement van Orde tot stand, zodat toen aan alle voorwaarden tot Statenontbinding was voldaan. Dit reglement maakt strenger optreden tegen ordeverstoring mogelijk; de voornaamste nieuwigheden eruit zijn:

$a$ instelling van een commissie van voorbereiding voor het uitbrengen van prae-advies op te behandelen onderwerpen;

$b$ debat bij ingekomen stukken is niet toegelaten;

$c$ een lid kan het woord worden ontnomen, hij kan van de vergadering

West-Indische Gids XXXII 


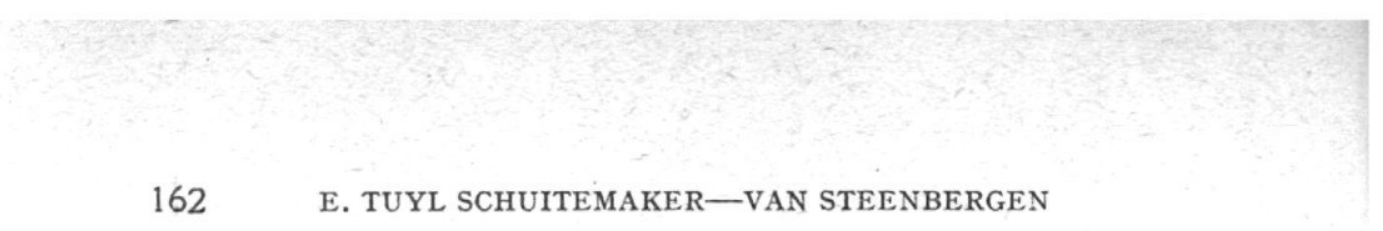

worden uitgesloten, en hij kan gedwongen worden het gebouw te verlaten;

$d$ het quorum is op 11 gesteld.

Voor de nieuwe verkiezingen werd als datum 14 Maart vastgesteld; het bijeenkomen der nieuwe Staten werd bepaald op 2 April. Maar voordat de verkiezingen een aanvang namen werden de gemoederen nog in beroering gebracht door de kwestie van uitsluiting van Indonesiërs bij de verkiezingen. De landsregering diende nml. op 13 Januari een ontwerp-landsverordening in bij de Staten betreffende het afvoeren van de op de kiezerslijsten voorkomende tot de inheemse bevolking van Indonesië behorende personen die $a$ buiten Nederland, Suriname of de Nederlandse Antillen geboren zijn en niet hebben verklaard dat zij de Nederlandse nationaliteit verkiezen en $b$ die in een van deze Rijksdelen geboren zijn en verklaard hebben de Indonesische nationaliteit te verkiezen. Dit ontwerp ging uit van de veronderstelling dat deze Indonesiërs geen Nederlandse onderdanen meer zijn, dus vreemdelingen, dus niet kiesgerechtigd.

De oppositie stelde hier tegenover:

1 volgens art. 8 (1) en (2) van de overgangsovereenkomst van de Wet Souvereiniteitsoverdracht Indonesië zijn de in Suriname wonende Indonesiërs Nederlandse onderdanen; de Wet op het Nederlands onderdaanschap is door geen enkele bepaling buiten werking gesteld; bovendien bepaalt art. 24 van het Uniestatuut dat onderdanen der Unieleden niet als vreemdelingen zullen worden behandeld;

2 bij vonnis van 5 April 1950 heeft de Kantonrechter in den Haag beslist dat een in Indonesië geboren Indonesiër, die volgens de RTC-overeenkomst de Indonesische nationaliteit had verkregen, het kiesrecht in Nederland niet heeft verloren, omdat hij Nederlands onderdaan was gebleven, zodat hij dus op de kiezerslijst geplaatst kon worden;

3 het kiesrecht mag niet ontnomen worden voordat de termijn van twee jaar is verlopen, die was toegestaan om zich uit te spreken over de nationaliteit die men wilde opteren, volgens de overeenkomst toescheiding staatsburgers bij de Wet op de Souvereiniteitsoverdracht Indonesië;

4 dit ontwerp houdt, in tegenstelling tot wat de regering daaromtrent beweert, een wijziging van het kiesreglement in (blijkens zijn art. 1 en 3), terwijl uitdrukkelijk de bedoeling was dat de oude Staten geen wijziging van het kiesreglement zouden behandelen;

5 de nationaliteitskwestie is geen interne aangelegenheid maar wordt bij de wet geregeld, dus de landsregering is onbevoegd (volgens art. 6 der Landsregeling) deze kwestie te regelen. Bij de Staten Generaal is reeds een ontwerp ingediend tot wijziging van de Wet op het Nederlanderschap.

In kringen van de N.P.S. zag men de indiening van dit ontwerp als een poging van de coalitie om meer zetels ter beschikking te krijgen in de Staten door uitschakeling van de Indonesiërs. Bij de behandeling in de Staten over het ontwerp staakten de stemmen. De K.T.P.I. zond een protesttelegram naar de Nederlandse regering en het Indonesische Hoge Commissariaat in den Haag.

Op 25 Januari kreeg de landsregering bericht dat volgens de Nederlandse regering de in Suriname gevestigde Indonesiërs hun kiesbevoegd- 
heid hebben behouden. Als argumenten voerde de Nederlandse regering de hiervoor genoemde punten 1, 2 en 4 aan.

Hierop trok de landsregering het ontwerp in.

Op ${ }_{5}$ Maart werden algemene verkiezingen gehouden. Van de partijen deden de P.S.V., de Neger Politieke Partij en de P.B.I.S. niet mee uit protest tegen de Statenontbinding; evenmin de D.N.P. Wel deden mee: de N.P.S., de V.H.P., de K.T.P.I., de C.S.P., de Congrespartij, de Surinaamse Werknemers Organisatie, de Paranam Mijnwerkersbond en de Billiton Mijnwerkersbond.

De N.P.S. kwam als overwinnaar uit de strijd met 13 zetels, daarop volgde de V.H.P. met 6 zetels en de K.T.P.I. met 2 zetels. De partijenverhouding in de nieuwe Staten is dus precies dezelfde als die in de oude. Tot voorzitter van de Staten werd gekozen de heer Lim APo.

Over de verkiezingen kan nog opgemerkt worden dat het aantal candidaten (42) gering was vergeleken met de vorige verkiezingen (86). In Paramaribo waren dit keer maar 13 candidaten gesteld in tegenstelling tot de 49 van de vorige keer. In de districten werd voornamelijk gestreden tussen Hindostanen en Javanen. De N.P.S. stelde alleen Creolen als candidaten. Slechts $28 \%$ van de kiesgerechtigden in Paramaribo (9863 van de 35.600 ) maakten van hun recht gebruik; in $194969 \%$ (22.000 van de 32.000).

Nadat de ministers BRAKKE, CURRIE en ZAAL hun portefeuilles ter beschikking van de Gouverneur hadden gesteld (de ministers Hewit en LichtVELD hadden dit al eerder gedaan) werd de opdracht tot de samenstelling van een nieuw kabinet gegeven aan de heren Lim Apo en Findlay. Op 5 April was het nieuwe kabinet samengesteld en wel als volgt: Drielsma - Binnenlandse Zaken, Alberga - Justitie en Politie, Financiën, Oliviera - Landbouw, Veeteelt en Visserij, Smit (N.P.S.) - Openbare Werken en Verkeer, Juglall (N.P.S.) - Onderwijs en Volksontwikkeling, CURrIE - Economische Zaken, Sociale Zaken.

Het voornemen bestond $\mathrm{mr}$ Buiskool in de regeringsraad op te nemen zodra het wettelijk mogelijk was gemaakt dat leden van het Hof van Justitie lid kunnen worden van de regeringsraad zonder verlies van hun positie bij het Hof. Mr Burskool voelde als primair bezwaar tegen deelname aan de nieuwe Landsregering, zelfs als de incompatibiliteit der beide ambten zou zijn opgeheven, het feit dat hij het Hof, waarvan hij President is, wegens ernstige onderbezetting niet kon verlaten. Inmiddels werden door de Staten op 16 April de ontwerp-landsverordeningen betreffende de rechterlijke macht aangenomen, inhoudende uitbreiding van het aantal rechters en opheffing van de onverenigbaarheid van de functies rechter en lid van de Regeringsraad. Op 4 Juni werd mr Buiskool in de Regeringsraad opgenomen en benoemd tot landsminister van Algemene Zaken en Volksgezondheid.

Met de verkiezing der nieuwe Staten en de vorming van het nieuwe kabinet is voorlopig althans een einde gekomen aan de politieke beroering in Suriname. De werkzaamheden der Staten vinden normaal voortgang; er werden enkele interpellaties behandeld, waarvan die over de komst der mariniers ter vervanging van de landmacht in Suriname in het middelpunt der belangstelling stond.

In deze door de heren Findlay, Pengel en Kolader ingediende 
interpellatie, die op 25 Juni door de Staten aangenomen werd, werd geprotesteerd tegen het feit dat de Nederlandse regering, zonder voorafgaand overleg met de Surinaamse regering, besloten had de Koninklijke Landmacht in Suriname te vervangen door mariniers, terwijl tevens ongerustheid werd uitgesproken over de positie van vele Surinaamse militairen en burgerpersoneel in dienst der K.L. Terecht werd opgemerkt en hier is ook de landsregering het mee eens, dat dit besluit ingaat tegen de interim-regeling, die bepaalt dat gemeenschappelijke aangelegenheden (zoals bv. defensie) in gemeen overleg geregeld zullen worden.

Ten aanzien van het lot der Surinamers bij de landmacht, heeft de Nederlandse regering met nadruk verklaard dat terdege met hun belangen rekening zal worden gehouden.

Bij de behandeling van de interpellatie op 26 Juli kwam het tot een met algemene stemmen aanvaarde motie waarin afkeuring werd uitgesproken over het optreden der Nederlandse regering, en de genomen maatregel onaanvaardbaar werd verklaard; met klem werd aangedrongen op terugroeping der mariniers. Het antwoord van de Nederlandse regering hierop was, dat de status quo gehandhaafd zal worden tot, na gepleegd overleg, een definitieve beslissing zal zijn genomen. Voorlopig blijven dus de landmacht èn het aanwezige mariniersdetachement in Suriname gehandhaafd.

Inmiddels worden voorbereidingen getroffen voor een Ronde Tafel Conferentie, die begin 1952 gehouden zal worden, en waar besprekingen zullen worden gevoerd over de toekomstige staatkundige positie van de Nederlandse Antillen en Suriname binnen het Koninkrijk nieuwe stijl. De voorlopige RTC, die in 1948 werd verdaagd, wordt ontbonden en de delegatie van deze RTC krijgt zijn ontslag. In Nederland is een commissie van voorbereiding gevormd, die tot taak heeft een ontwerp-statuut op te stellen dat als basis voor de besprekingen kan dienen.

De Staten van Suriname hebben er op aan gedrongen dat de RTC nog dit jaar zal worden gehouden en deden een voordracht aan de landsregering van 7 personen als vertegenwoordigers van Suriname op de aanstaande RTC. Alle voorgedragen personen, op één na, zijn lid van de Staten en behoren tot de N.P.S., de V.H.P. en de K.T.P.I. Aanwijzing der delegatieleden zal geschieden nadat de Koningin de landsregering daartoe heeft uitgenodigd.

De P.S.V. heeft, naar aanleiding van deze voordracht, in een algemene vergadering een motie aangenomen waarin de wens tot uiting komt een RTC-delegatie op zo breed mogelijke basis samen te stellen. Daar de Staten slechts door $30 \%$ der kiezers zijn gekozen, en dus niet het gehele volk vertegenwoordigen, eist de P.S.V. ook een plaats in de RTC-delegatie.

Volgens De West behoort de delegatie alleen uit de in de Staten zitting hebbende politieke partijen samengesteld te worden.

De landsregering is van mening dat de voorbereiding van de RTC niet alleen bij Nederland, maar ook bij Suriname en de Nederlandse Antillen moet berusten, teneinde door voorafgaande uitwisseling van standpunten de conferentie zelf zo vlot mogelijk te kunnen doen verlopen. Met een delegatie van de Nederlandse Antillen heeft de landsregering besprekingen gevoerd over de te houden RTC; de resultaten hier- 
van zijn niet bekend gemaakt, slechts is bekend dat er volledige overeenstemming is bereikt.

Van de activiteit der voorbereidingscommissie zal het afhangen wanneer de RTC plaats zal vinden.

\section{HET QUURUM}

Buisкool meent: In art. 92 van de Landsregeling wordt in lid (1) met ,,de helft van het aantal leden" bedoeld de helft van het feitelijk aantal in tegenstelling tot art. 185, waarin in lid (3) wordt gesproken over , het wettelijk aantal leden'. Er bestaat een bewust gemaakt verschil tussen beide artikelen.

Het standpunt van vAN DER SCHROEFF is: dat er absoluut geen verschil tussen beide artikelen bestaat, maar dat in beide gevallen het wettelijk aantal leden bedoeld wordt.

Argumenten van de heer Buiskool:

In Regeringsreglement 1865 dat tot 1936 heeft gegolden stond in art. 86: "meer dan de helft der leden".

In Staatsregeling 1936 stond in art. 86: ", ten minste 8 leden"; het aantal Statenleden was 15.

In Staatsregeling 1948 stond in art. 96: ,, meer dan de helft van het aantal leden".; hier stond expres niet: ten minste 11 leden, omdat men niet bedoelde dat altijd meer dan de helft van het wettelijk aantal der Statenleden tegenwoordig moest zijn; men wilde rekening houden met vacatures, daarom werd het systeem van het Regeringsreglement 1865 overgenomen. Vóór 1936 was het absoluut uitgesloten om een vaste wettelijke helft te bepalen, daar in art. 68 van RR 1865 stond, dat de Staten uit niet minder dan 13 en niet meer dan 25 leden konden bestaan, dus een vast wettelijk aantal bestond niet, dus art. 86 bedoelde ,feitelijk aantal". In 1936 stelde men wel een vast aantal van minstens 8 leden vast, omdat er een vast wettelijk aantal van 15 Statenleden was, waarvan 5 werden benoemd. In 1948 werden alle leden weer gekozen en keerde men terug tot het systeem van vóór 1936.

Het Reglement van Orde, dat het quorum vaststelt op de helft plus 1 van het wettelijk aantal, kan de wet niet opzij zetten. In tegenstelling tot het ,,feitelijk aantal" van art. 92 van de Landsregeling spreekt art. 185 van het „,wettelijk aantal" omdat men voor de in dit artikel genoemde gevallen een versterkte meerderheid van 14 stemmen wilde hebben, ongeacht het feitelijk ledental.

Tenslotte beroept BuIsKOoL zich op de omstandigheid dat in het Nederlands en ook in het Indonesisch staatsrecht bij de berekening van het quorum meestal wordt uitgegaan van het feitelijk ledental.

Argumenten van de heer van der Schroeff:

De Staten bestonden tot 1936 in de praktijk uit 13 leden, ongeacht de mogelijkheid van een groter aantal. Het quorum was 7 , want de Staten hebben tientallen jaren de helft van het aantal leden opgevat als ,,de helft van het wettelijk aantal leden". In 1936 werd eenvoudig de bestaande opvatting in cijfers vastgelegd; het systeem van berekening van het quorum werd toen niet plotseling gewijzigd. In de toelichting van de regering bij art. 86 van de Staatsregeling 1948 werd gezegd: de wijziging van art. 86 is geheel in overeenstemming met de algemeen 
gevolgde gedragslijn; dit betekent dus volgens v. D. SchroefF dat de helft van het wettelijk aantal leden bedoeld wordt. Er is geen verschil tussen art. 185 en art. 92 van de Landsregeling 1950; art. 185 verduidelijkt alleen de bedoeling van art. 92. In art. 185 ligt de nadruk niet op , ,het wettelijk aantal”, want dit spreekt vanzelf, maar op ,,tweederde van het aantal".

\section{Het KiesReglement}

Het bestaande kiesreglement dateert van 1948 (Gouvernementsblad $I 6 I$ ). Het huldigt, in tegenstelling tot het ontwerp dat een evenredigheidslijstenstelsel gaf, een districtenstelsel met gewone meerderheid. De verkiezingen werden gehouden in 9 kieskringen $(G B$ '48-I62) waarover de zetels als volgt verdeeld zijn: Paramaribo 10, Commewijne, Saramacca en Nickerie elk 2, de overige 5 kieskringen elk 1.

In de afgelopen maanden is, zoals boven bleek, veel over dit kiesstelsel te doen geweest. Het grote euvel ervan was dat de kleinere partijen niet aan bod kwamen door het meerderheidsstelsel. Bovendien gingen er veel stemmen verloren en daarbij kwam nog het nadeel van tussentijdse verkiezingen. De N.P.S. was tegen wijziging van het kiesreglement vóór de nieuwe verkiezingen, daar zij ongetwijfeld in Paramaribo minder zetels zou veroveren wanneer evenredige vertegenwoordiging werd doorgevoerd. Vóór wijziging waren de P.S.V., de V.H.P., de Hindustaanse Oranje Partij, de C.S.P. en de Congrespartij.

In Augustus 1950 stelde mr Buiskool een plan op voor een nieuw kiesstelsel, dat voor Suriname geschikt zou zijn. Hierbij zou aan de bezwaren tegen het districtenstelsel met persoonlijke meerderheidskeuze (onderdrukking der minderheden, tussentijdse verkiezingen, verdeling. in kieskringen met eigen zetels) en aan die tegen evenredige vertegenwoordiging met lijstenstelsel (onbekendheid van de kiezers met de gekozen candidaten, versnippering in vele kleine partijen) worden tegemoet gekomen. In Suriname is het persoonlijk element in de verkiezingen van belang en daarom stelde Buiskool voor een evenredigheidspersonenstelsel zonder kiesdistricten (dus geen tussentijdse verkiezingen meer ter voorziening in vacatures). Het ledental der Staten zou niet vaststaan, maar wisselen, nml. worden bepaald naar het totaal aantal uitgebrachte stemmen, gedeeld door een vaste kiesdeler.

In October 1950 verzocht de landsregering de grondwetscommissie (ingesteld bij resolutie van 18 Maart $1950 \mathrm{n}^{\circ}$. 1376) om advies uit te brengen over de vraag of het kiesreglement gewijzigd moest worden, en zo jà, hoe. De commissie deelde echter mee dat dit buiten haar opdracht lag.

In Februari 1951 diende de landsregering een ontwerp-landsverordening in tot wijziging van het kiesreglement (samengesteld door een commissie onder leiding van mr BuIsKooL). Het ontwerp stelt een evenredigheidspersonenstelsel voor. Er zal een nieuwe verdeling in administratieve kieskringen tot stand worden gebracht, voorlopig twee, nml. de stad Paramaribo, die 10 leden afvaardigt en het platteland dat er 11 kiest. Hiertoe zal art. 72 (3) van de Landsregeling moeten worden gewijzigd. 


\section{E Parlementaire onschendbatrheid}

Belangrijk is het proces-Findlay, daar hierin door de rechter in eerste aanleg en door het Hof van Justitie een uitspraak werd gedaan met betrekking tot de parlementaire onschendbaarheid.

De aanklacht van de Districts-Commissaris van Paramaribo tegen de heer Findlay, hoofdredacteur van het dagblad De West, bevatte 4 punten; 3 hiervan betroffen publicaties in De West van passages die waren overgenomen uit een weekblad dat om dezelfde passages in beslag was genomen; één der punten betrof belediging van landsminister LichtVElD door de heer Findlay, die de minister ,,gangster" noemde in de vergaderzaal der Staten terwijl de vergadering geschorst was (28 Aug. 1950).

De rechter stelde zich op het standpunt dat, ook al was de openbare vergadering geschorst en werden de beraadslagingen in comité voortgezet, de eigenlijke Statenvergadering voortduurde; en voorts dat het van geen belang is of de beklaagde zich al dan niet bevond in het vertrek (i.c. de kotfiekamer) waar het parlementair debat plaats vond. De heer FindLAY werd dus voor hetgeen hij in de vergadering zeide beschermd door art. 92 van de Landsregeling, en vrijgesproken van het ten laste gelegde in punt 4.

Ten aanzien van de overname in zijn blad van beledigende passages werd hij veroordeeld tot $f 25$ boete, waarop de heer FindLAY om principiële redenen in hoger beroep ging. Ook de ambtenaar O.M. ging in hoger beroep. Bovendien stelde het Parket een vervolging in tegen enkele dagbladen die door hun critiek op dit vonnis de rechterlijke macht beledigden; De Surinamer noemde het ,een politiek vonnis” terwijl ook Het Nieuws in deze zin insinueerde.

De uitspraak van het Hof van Justitie bevestigde de parlementaire onschendbaarheid van FindLAY ten tijde van het incident in de Statenvergadering van 28 Augustus 1950. Tevens werd de beklaagde ontslagen van alle rechtsvervolging ten aanzien van de overdruk van beledigende passages uit het weekblad Makka.

Uit deze uitspraak is gebleken dat het Hof van Justitie van oordeel is dat:

$a$ de parlementaire onschendbaarheid geldt voor de gehele ruimte die ter beschikking van het parlement staat (dus niet alleen de vergaderzaal);

$b$ een vergadering voortduurt totdat zij gesloten of verdaagd is; een geschorste vergadering is een voortdurende vergadering.

In April 1951 deed het Hof uitspraak in de zaak tegen de hoofdredacteur van De Surinamer, Pater Willebrands, die rechter HaverSснміDт beledigd had door zijn vonnis over de zaak FindLAy een ",politiek vonnis" te noemen. Het Hof sprak Pater Willebrands vrij.

Political development in Surinam after the introduction of the INTERIM-CONSTITUTION

This article gives a survey of the existing political parties and the difficulties in the parliament of Surinam during the period from January 1950 till September 1951. 
B O U W T E E N T E S

Gouverneur A. A. M. Struycken - wiens portret men in deze aflevering ziet afgedrukt - werd op 27 Dec. 1906 te Breda geboren, studeerde rechten aan de R.K. Universiteit te Nijmegen en deed aldaar zijn doctoraal examen op 29 Jan. 1932. Hierna werd hij advocaat en procureur te Breda en tevens waarnemend griffier bij de arrondissementsrechtbank; in 1935 gemeenteraadslid, in 1937 voorzitter van de R.K. raadsfractie, in 1938 wethouder en lid van de Prov. Staten voor N.-Brabant.

Mr StRUyCKen werd - nadat hij in 1941 als wethouder had bedankt - belast met de leiding van de sociale dienst van de N.V. Hollandsche Kunstzijde-Industrie te Breda, met opdracht de sociale ontwikkeling voor te bereiden, welke de na-oorlogse structuur zou eisen. Van $4 \mathrm{Mei}$ 1942 t/m Dec. 1943 werd hij door de Duitsers als gijzelaar geïnterneerd in het kamp te St Michielgestel. In 1944 hield hij zich bezig met de organisatie van de Orde-Dienst district Breda en de financiering van de spoorwegstaking West-Brabant.

$\mathrm{Na}$ de bevrijding van het Zuiden werd mr STRUYCKEN wethouder van bedrijven/financiën, speciaal belast met de zorg voor vluchtelingen en evacué's, loco-burgemeester, en later wethouder van onderwijs en cultuur. Hij trachtte, bij de inwerkingtreding van de tribunalen, door fel omstreden artikelen in ,De Stem”, het debat te openen over de behandeling en berechting van politieke delinquenten, teneinde tot redelijke afgrenzing van het probleem te komen. Hij was o.m. voorzitter van Het Wit-Gele Kruis Breda, de St. Adelbertus-Vereniging Breda, het Maatschappelijk Comité Breda, de Advies-Commissie v.h. Gewestelijk Arbeidsbureau en de Stichting Brabantsch Orkest; secretaris van het Departement Breda van de Mij. voor Nijverheid en Handel en de R.K. Werkgeversvereniging diocees Breda.

Mr Struycken was Minister van Justitie van $8 \mathrm{Juli} 1950$ tot $13 \mathrm{Mrt}$ 1951. Bij K.B. van 13 Apr. 1951 werd hij benoemd tot Gouverneur van de Nederlandse Antillen. Op 6 Juni zette hij, op het vliegveld Hato, voor het eerst zijn voet op Antilliaanse bodem.

Willem Benjamin van Panhuys, geboren 5 Dec. 1764 te Maastricht, werd in 1778 cadet, in 1783 kapitein, in 1788 majoor en in 1793 luit. kolonel. Maakte de veldtochten mede in de Oostenrijkse Nederlanden tegen de Fransen, nam deel aan de slag van Fleurus in 1794. Huwde voor de le maal met Alexandrina Elisabeth REynsdorp (overl. 1797 te Eisenach), kleindochter van de Raad van Civiele justitie in Suriname. In 1800 vertrok vaN PANHUYS naar Suriname ter regeling van een erfkwestie. Hij huwde voor de $2 \mathrm{e}$ maal met Louise Frederico Auguste baronesse van Barekhaus Wiesenhütten (geb. 1763). Hij was zeer oranjegezind en nam eervol ontslag op 10 Mei 1814 (met de titul. rang van gen. majoor). Hij verzocht in 1815 naar Suriname te worden gezonden. Als gouverneur-generaal naar Suriname vertrokken (de tweede met die titel; de eerste was DE FRIDERICI) ter overneming van de kolonie van de Engelsen, kwam hij 15 Jan. 1816 aldaar aan en nam bij proclamatie van $27 \mathrm{Febr}$. het bewind over. Na een korte ziekte overleed hij op $18 \mathrm{Juli} 1816$ en werd in de Nieuwe Oranje Tuin te Paramaribo begraven. Zie voor zijn grafzerk , De Nederlandsche Leeuw” van April 1942, nr. 422.

O.D. 